
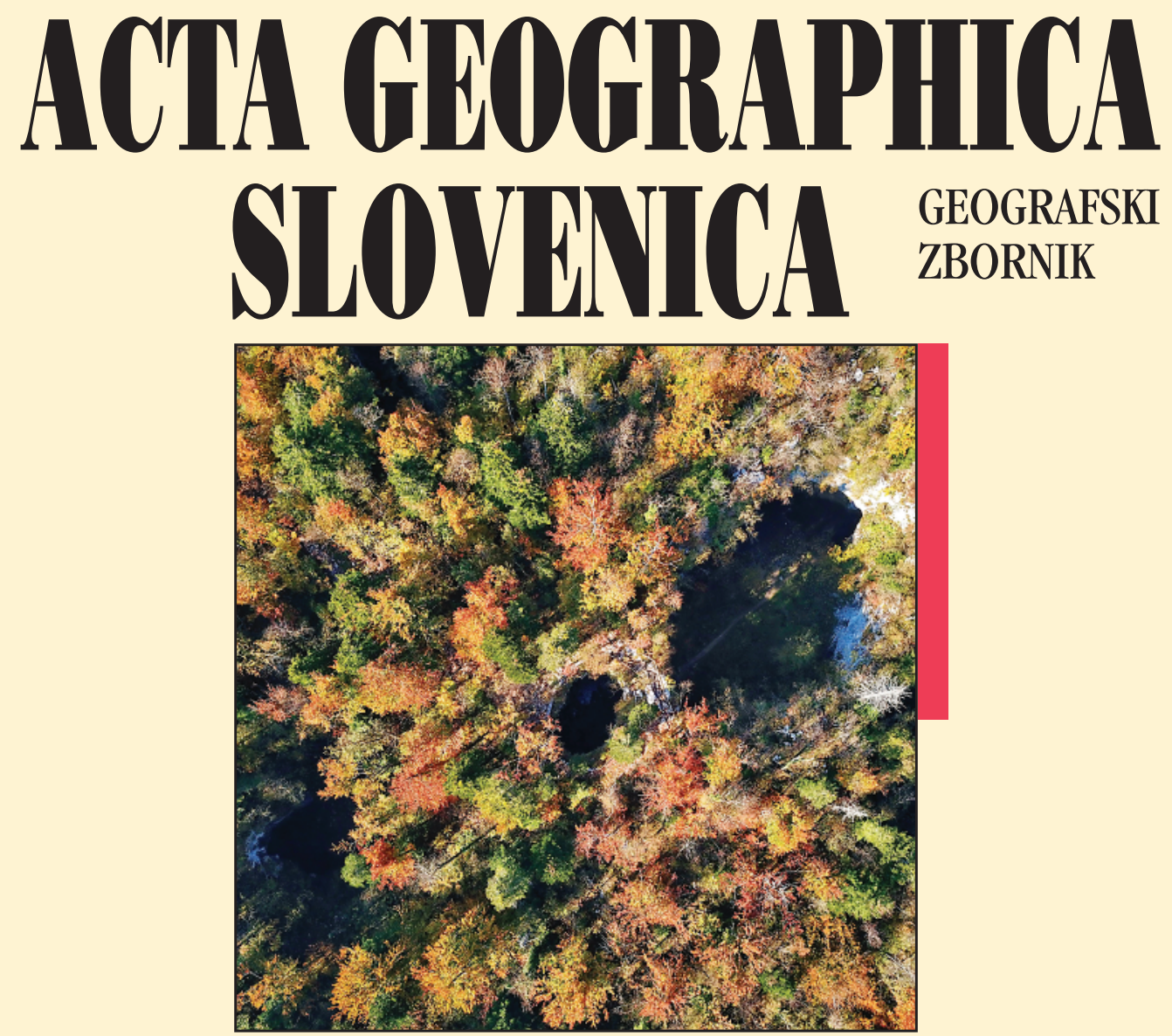


\section{ACTA GEOGRAPHICA SLOVENICA GEOGRAFSKI ZBORNIK \\ $59-2 \cdot 2019$}

\section{Contents}

Drago PERKO, Rok CIGLIČ, Mauro HRVATIN

The usefulness of unsupervised classification methods for landscape typification: The case of Slovenia

Vladimir M. CVETKOVIĆ, Kevin RONAN, Rajib SHAW, Marina FILIPOVIĆ, Rita MANO, Jasmina GAČIĆ, Vladimir JAKOVLJEVIĆ

Household earthquake preparedness in Serbia: A study of selected municipalities

Iwona CIEŚLAK

Spatial conflicts: Analyzing a burden created by differing land use

Ivan PAUNOVIĆ, Verka JOVANOVIĆ

Sustainable mountain tourism in word and deed: A comparative analysis in the macro regions of the Alps and the Dinarides

Nikola Darko VUKSANOVIĆ, Dragan TEŠANOVIĆ, Bojana KALENJUK, Milijanko PORTIĆ Gender, age and education differences in food consumption within a region: Case studies of Belgrade and Novi Sad (Serbia)

\section{Special issue - Franciscean cadaster as a source of studying landscape changes}

Matej GABROVEC, Ivan BIČÍK, Blaž KOMAC

Land registers as a source of studying long-term land-use changes

Ivan BIČÍK, Matej GABROVEC, Lucie KUPKOVÁ

Long-term land-use changes: A comparison between Czechia and Slovenia

Lucie KUPKOVÁ, Ivan BIČÍK, Zdeněk BOUDNÝ

Long-term land-use / land-cover changes in Czech border regions

Drago KLADNIK, Matjaž GERŠIČ, Primož PIPAN, Manca VOLK BAHUN

Land-use changes in Slovenian terraced landscapes

Daniela RIBEIRO, Mateja ŠMID HRIBAR

Assessment of land-use changes and their impacts on ecosystem services in two Slovenian rural landscapes

Mojca FOŠKI, Alma ZAVODNIK LAMOVŠEK

Monitoring land-use change using selected indices

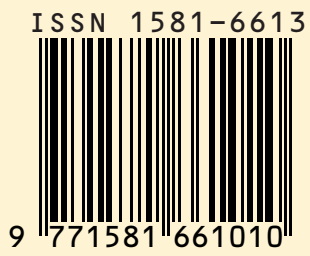




\section{ACTA GEOGRAPHICA SLOVENICA}

$59-2$

2019

ISSN: 1581-6613

COBISS: 124775936

UDC/UDK: 91

(C) 2019, ZRC SAZU, Geografski inštitut Antona Melika

International editorial board/mednarodni uredniški odbor: David Bole (Slovenia), Michael Bründl (Switzerland), Rok Ciglič (Slovenia), Matej Gabrovec (Slovenia), Matjaž Geršič (Slovenia), Peter Jordan (Austria), Drago Kladnik (Slovenia), Blaž Komac (Slovenia), Andrej Kranjc (Slovenia), Dénes Lóczy (Hungary), Simon McCharty (United Kingdom), Slobodan Marković (Serbia), Janez Nared (Slovenia), Drago Perko (Slovenia), Marjan Ravbar (Slovenia), Nika Razpotnik Visković (Slovenia), Aleš Smrekar (Slovenia), Annett Steinführer (Germany), Mimi Urbanc (Slovenia), Matija Zorn (Slovenia)

Editor-in-Chief/glavni urednik: Blaž Komac; blaz@zrc-sazu.si

Executive editor/odgovorni urednik: Drago Perko; drago@zrc-sazu.si

Chief editor for physical geography/glavni urednik za fizično geografijo: Matija Zorn; matija.zorn@zrc-sazu.si Chief editor for human geography/glavna urednica za humano geografijo: Mimi Urbanc; mimi@zrc-sazu.si

Chief editor for regional geography/glavni urednik za regionalno geografijo: Drago Kladnik; drago.kladnik@zrc-sazu.si

Chief editor for spatial planning/glavni urednik za regionalno planiranje: Janez Nared; janez.nared@zrc-sazu.si

Chief editor for rural geography/glavna urednica za geografijo podeželja: Nika Razpotnik Visković; nika.razpotnik@zrc-sazu.si Chief editor for urban geography/glavni urednik za urbano geografijo: David Bole; david.bole@zrc-sazu.si

Chief editor for geographic information systems/glavni urednik za geografske informacijske sisteme: Rok Ciglič; rok.ciglic@zrc-sazu.si

Chief editor for environmental protection/glavni urednik za varstvo okolja: Aleš Smrekar; ales.smrekar@zrc-sazu.si

Editorial assistant/uredniški pomočnik: Matjaž Geršič; matjaz.gersic@zrc-sazu.si

Issued by/izdajatelj: Geografski inštitut Antona Melika ZRC SAZU

Published by/založnik: Založba ZRC

Co-published by/sozaložnik: Slovenska akademija znanosti in umetnosti

Address/Naslov: Geografski inštitut Antona Melika ZRC SAZU, Gosposka ulica 13, SI - 1000 Ljubljana, Slovenija

The papers are available on-line/prispevki so dostopni na medmrežju: http://ags.zrc-sazu.si (ISSN: 1581-8314)

Ordering/naročanje: Založba ZRC, Novi trg 2, p. p. 306, SI - 1001 Ljubljana, Slovenija; zalozba@zrc-sazu.si

Annual subscription/letna naročnina: $20 €$ for individuals/za posameznike, $28 €$ for institutions/za ustanove.

Single issue/cena posamezne številke: $12,50 €$ for individuals/za posameznike, $16 €$ for institutions/za ustanove.

Cartography/kartografija: Geografski inštitut Antona Melika ZRC SAZU

Translations/prevodi: DEKS, d. o. o.

DTP/prelom: SYNCOMP, d. o. o.

Printed by/tiskarna: Tiskarna Present, d. o. o.

Print run/naklada: 450 copies/izvodov

The journal is subsidized by the Slovenian Research Agency and is issued in the framework of the Geography of Slovenia core research programme (P6-0101)/revija izhaja s podporo Javne agencije za raziskovalno dejavnost Republike Slovenije in nastaja v okviru raziskovalnega programa Geografija Slovenije (P6-0101).

The journal is indexed also in/revija je vključena tudi v: SCIE - Science Citation Index Expanded, Scopus, JCR - Journal Citation Report/Science Edition, ERIH PLUS, GEOBASE Journals, Current geographical publications, EBSCOhost, Geoscience e-Journals, Georef, FRANCIS, SJR (SCImago Journal \& Country Rank), OCLC WorldCat, Google scholar, and CrossRef

Oblikovanje/Design by: Matjaž Vipotnik

Front cover photography: Exploration of the collapse dolines, such as the one at the Small Natural Bridge in Rakov Škocjan, has enabled a deeper understanding of karst processes in recent years (photograph: Matej Lipar).

Fotografija na naslovnici: Raziskave udornice, kot je ta pri Malem Naravnem mostu v Rakovem Škocjanu, so v zadnjih letih omogočile globlje razumevanje kraških procesov (fotografija: Matej Lipar). 


\section{SUSTAINABLE MOUNTAIN TOURISM IN WORD AND DEED: A COMPARATIVE ANALYSIS IN THE MACRO REGIONS OF THE ALPS AND THE DINARIDES}

Ivan Paunović, Verka Jovanović

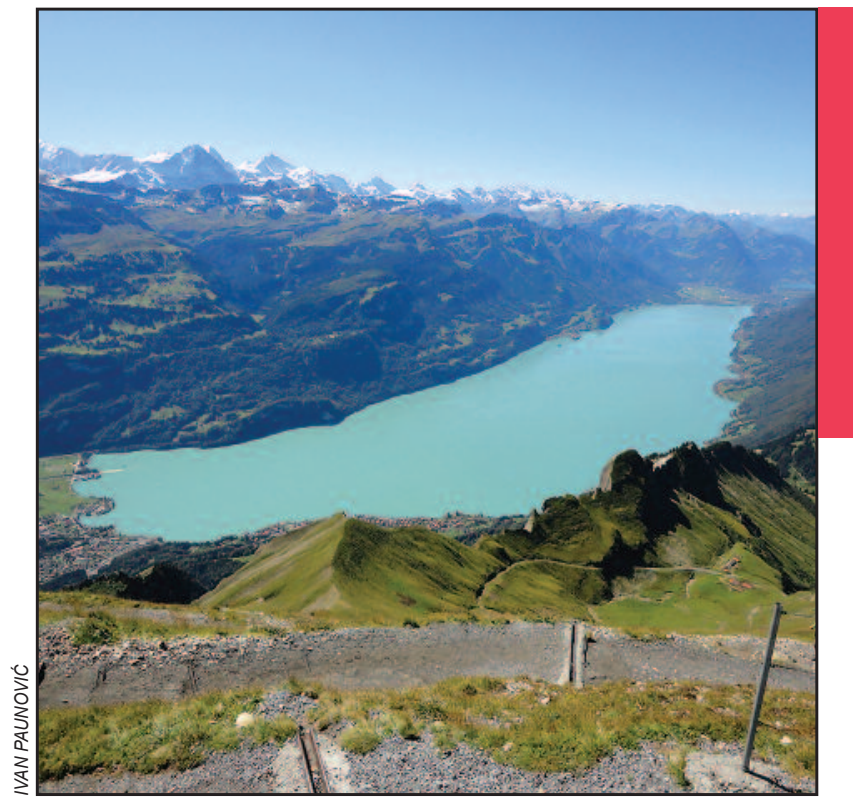

Sustainable mountain tourism can contribute significantly to sustainable development in the Alps and Dinarides. 


\title{
Sustainable mountain tourism in word and deed: A comparative analysis in the macro regions of the Alps and the Dinarides
}

\begin{abstract}
This article examines similarities and differences in the attitudes and social representations of destination managers towards implementing sustainable tourism between the mountain regions of the Alps and the Dinarides. Bearing in mind the transnational impacts (i.e., environmental, economic and social) of the tourism industry the research methodology adopted an international perspective by sending a questionnaire to tourism organizations in fourteen different countries in the Alps and the Dinarides. The research is interdisciplinary in nature, because it integrates knowledge from sustainability and management science with tourism geography and social psychology. The findings confirm that social representations of sustainable tourism differ significantly in the two mountain regions.
\end{abstract}

KEY WORDS: Sustainability, tourism geography, governance, mountain tourism, social representations of tourism, Alps, Dinarides

\section{Trajnostni gorski turizem $\mathrm{v}$ besedi in dejanju: primerjalna analiza $\mathrm{v}$ makroregijah Alp in Dinarskega gorstva}

IZVLEČEK: V članku avtorja preučujeta podobnosti in razlike v odnosu destinacijskih menedžerjev do izvajanja trajnostnega turizma na gorskih območjih Alp in Dinaridov oziroma primerjata socialne reprezentacije trajnostnega turizma na teh dveh območjih. Ker ima turistična dejavnost transnacionalne (okoljske, ekonomske in socialne) vplive, sta avtorja opravila mednarodno raziskavo, v kateri sta vprašalnike poslala turističnim organizacijam v 14 različnih državah na območju Alp in Dinarskega gorstva. Raziskava je interdisciplinarna, saj združuje znanja s področij trajnostnega razvoja, managementa, turistične geografije in socialne psihologije. Njeni izsledki potrjujejo, da se socialne reprezentacije trajnostnega turizma med obema preučevanima gorskima območjema precej razlikujejo.

KLJUČNE BESEDE: trajnostnost, turistična geografija, upravljanje, gorski turizem, socialne reprezentacije turizma, Alpe, Dinarsko

\section{Ivan Paunović, Verka Jovanović}

Singidunum University

paun.bg@gmail.com, vjovanovic@singidunum.ac.rs

The article was submitted for publication on July $19^{\text {th }} 2016$.

Uredništvo je prejelo prispevek 19. julija 2016. 


\section{Introduction}

In the Alps, sustainable development became an important paradigm at the level of the macro region soon after the publication of the report »Our Common Future «y the Brundtland Commission, through the first Alpine conference in Berchtesgaden in 1989, and ever since a coordinated transnational research has been conducted in the Alps through the Alpine Convention. (Borsdorf et al. 2015; WCED 1987). In the Dinarides however, there are still no strong transnational and cross-disciplinary political initiatives or research on sustainable development. This situation points to the potential differences in the social representations of sustainable tourism in the Dinarides. This article therefore opens a discussion on the governance and sustainability of tourism from the perspective of the mountain destination managers in the two macro regions: the Alps and the Dinarides. The Alps are a natural benchmark for the Dinarides not only as their closest neighbor but also as one of the leading mountain chains regarding research on the environmental and social impacts of mountain tourism. The article investigates the phenomenon of sustainable tourism in the Alps and the Dinarides as an interdisciplinary field of research between tourism geography, social psychology, sustainability science and management science.

The Brundtland Commission has defined sustainable development as: »... development that meets the needs of the present without compromising the ability of the future generations to meet their own needs" (WCED 1987), and other institutions (UNEP and UNWTO 2005) emphasize that at the center of sustainable development are interdisciplinary perspectives (involving the economy, society, and environment) and global perspectives as well as ethical conduct. This means that sustainable destination planning and development are directly connected to destination values and leadership. Elaković (2011) correctly notes that a critical-realistic approach to destination development (with humanistic values at its core) marks the mature phase of tourist destination development. The author further clarifies that improving leadership and management values is a task for every ethical manager in order to improve the full scope of organisational activites and lessen their negative impacts on the environment. In this sense, there is very little research on the social representations of tourism (Moscardo 2011), and none has been conducted on sustainable mountain tourism. Social representations are a specific way of understanding and communicating existing knowledge, somewhere between the raw concepts and percepts, which give meaning to the world around us (Moscovici and Duveen 2000). In short, representation is an image or a meaning. Social representations in tourism are what communities and other stakeholders believe or interpret about tourism and its impacts (Moscardo 2011). The central actor, whose social representation of sustainable tourism has been studied in this article are the destination management organizations (DMO) in the Alps and the Dinarides. DMO's are a central actor in coordination of various tourism stakeholders and as such they usually have the most knowledge about different types of destination stakeholders.

Moscardo's (2011) analysis of tourism planning models in emerging destinations demonstrated that the predominant paradigm is a business approach, whereas sustainability issues have been totally neglected in most cases. Government planning has been considered by many as partly outdated and partly unnecessary, but effective management systems for sustainable tourism very often need government planning (Bramwell and Lane 2011). The two main factors shaping the planning of mountain and ski tourism are demographic change-as the most important factor, and climate change-as the second most important factor (Gössling and Scott 2012). However, this order is predicted to shift by the end of the century, when climate change will become the most important factor, and demographic change the second most important factor. Organizational approaches to this changes can vary from total rejection of a sustainability agenda and non-responsiveness, through compliance, eco-efficiency or strategic sustainability, all the way to ideological commitment (Dunphy and Benveniste 2000).

Destination values and strategic directions always directly reflect destination leadership which is set in an inter-organizational context through distributed and systemic leadership (Pechlaner, Kozak and Volgger 2014). Leadership is considered by many to be a missing link in destination management theory (Bieger and Beritelli 2013). This is because the concepts of governance and networking go hand in hand, but are only able to resolve the issues of processes and how things are done, whereas the question of goals and strategies should be addressed through a framework of leadership or generally a more humanistic approach (Volgger and Pechlaner 2015). Having all this in mind, Waligo, Clarke and Hawkings (2013) note that leadership is essential in creating a common understanding about the values of sustainable development and 
its implementation at the destination. However, according to Yasarata et al. (2010), a pressurized political context as well as politicians' attitudes and values in some countries can significantly alter the implementation of sustainable development policies, compared to the original plans.

The destination actors that have the power to choose or change the nature of tourism development can have a key impact on spreading the benefits of tourism development to the development of the entire destination and local community (Moscardo 2005). The most important aspect of this power is whether and how much it is based on knowledge. However, the problem with many developing destinations is that destination residents have a small or limited role in tourism planning, whereas the development is directed by foreign tour operators, often power-distant government departments and destination management organisations (Moscardo 2011). Mountain destinations in most of the Dinarides are definitely developing destinations where these kinds of issues are present, which is why development priorities should be compared to those of more developed mountain destinations, such as those in the Alps.

The main goal of this article is to determine whether there are any differences in the social representations of sustainable tourism that affect the realization of sustainable tourism in the Alps compared to the Dinarides. The goal is also to identify the triggers of destination management differences that result in various problems in implementating sustainable tourism development. In this sense, the following four research questions have been developed:

1. How great is the importance of various stakeholders to destination management?

2. How great is the implementation of sustainability principles in destination planning?

3. What are the leadership or management values practiced at the destination?

4. What are the priorities of destination development?

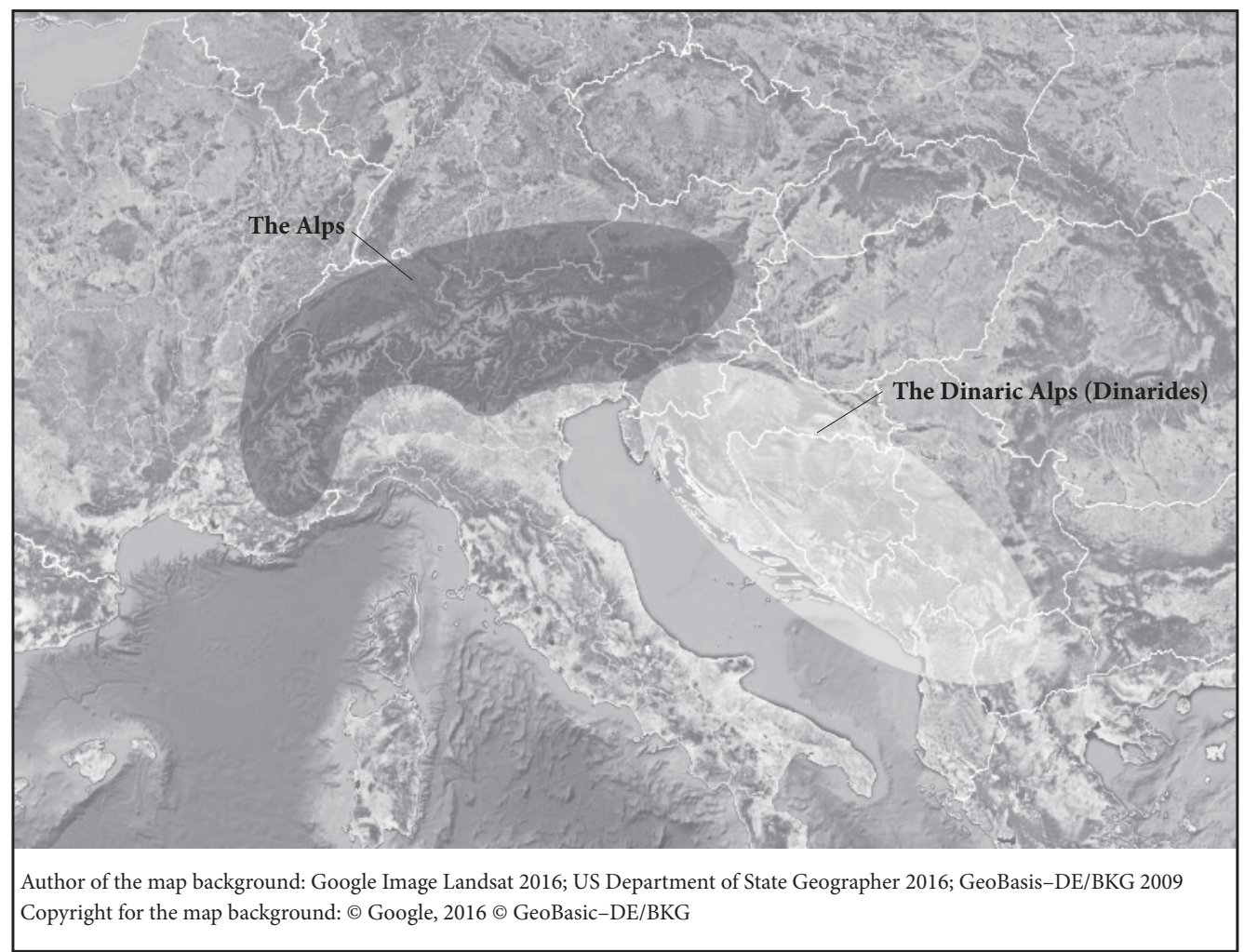

Figure 1: Position of the researched mountain areas in Europe: The Alps and the Dinarides. 


\section{Methods}

The research method used in this study was a questionnaire, and the sampling method was judgment sampling used as a nonprobability method, which means that sample was selected based on judgment. The questionnaire was translated into six languages and it used a seven-point Lickert scale for all of the questions (a five-point was not used intentionally, in order to avoid mistakes because there are, for example, differences in school grading in different countries), on which 7 was the highest score. The questionnaire was sent out via e-mail and as an online questionnaire (respondent could choose which one to use) to selected DMOs in areas over $1000 \mathrm{~m}$ in elevation. Altogether, 1,213 organizations where included and seventy of them replied. The relatively low response rate $(5.77 \%)$ was expected, given that previous research (Finkelstein, Hambrick and Cannella 2009) had indicated that professionals in management positions are not inclined to participate in research on leadership values. The distribution of the data collected is as follows: fourty-six in the Alps (six France, one in Liechtenstein, nine in Italy, seven in Germany, two in Alpine Slovenia, nine in Austria, and twelve in Switzerland) and twenty-four in the Dinarides-24 (one in Albania, ten in Bosnia and Herzegovina, three in Montenegro, one in Croatia, zero in Kosovo, four in Macedonia, one in Dinaric Slovenia, and four in Serbia). The research included the following types of organizations: tourism organizations, departments/sections for tourism and/or economic development (in charge of tourism) in local municipal institutions, regional tourism organizations, tourism societies, destination marketing organizations and regional development organizations.

In the analysis phase, MS Excel was used to calculate the descriptive statistics, as well as SPSS to calculate statistical significance using t-tests. In the graphs and tables, statistical significance at the 0.05 level is marked with two asterisks. In this sense, it is important that the two samples (the Alps and Dinarides) were relatively well-balanced, because there is no statistically significant difference between the two groups in age, level of education, or any key competency of the respondents. The only statistically significant difference was in the sex of the respondents; there were more women in the Alps sample.

\section{Results}

The results on the social representations of sustainable tourism in the management practice cover the following aspects of the destination management process in the two mountain regions: the importance given to the different types of stakeholders by the DMO (Figure 2), planning for sustainability at the destination (Figure 3 and Table 1), leadership/management values at the destination (Figure 4), and priorities of the destination development (Table 2). In all of the following tables and graphs, two asterisks »** « indicates statistically significant difference at the 0.05 level.

Figure 2 shows that there are significant differences in stakeholder prioritization by the destination management organizations between the Alps and the Dinarides. One very important difference is that stakeholders are more evenly ranked in the Dinarides, whereas the three most important stakeholders are clearly more important than the other stakeholders in the Alps.

As shown in Figure 3, self-evaluations about the implementation of sustainability principles in destination planning show a small difference. However, the differences between evaluation in word only and concrete actions become somewhat clearer in Table 1, Figure 4 and Table 2.

Table 1: Planning for sustainability.

\begin{tabular}{llc}
\hline Feature & \multicolumn{2}{c}{ Likert scores (rank) } \\
\cline { 2 - 2 } & Alps & Dinarides \\
\hline Multidisciplinary sustainable development planning documents & $4.17(3 \mathrm{rd})$ & 3.77 \\
Economic/tourism development documents & $4.94(1 \mathrm{st})$ & $4.05(3 \mathrm{rd})$ \\
**Environmental protection documents & $4.26(2 \mathrm{nd})$ & $5.64(1 \mathrm{st})$ \\
Separate cost-benefit analyses & 2.98 & 3.14 \\
**Legislation (constitutional, environmental, economic/tourism, etc.) & 4.06 & 5.18 (2nd) \\
Other & 1.72 & 1.72 \\
\hline
\end{tabular}




\section{Public institutions}

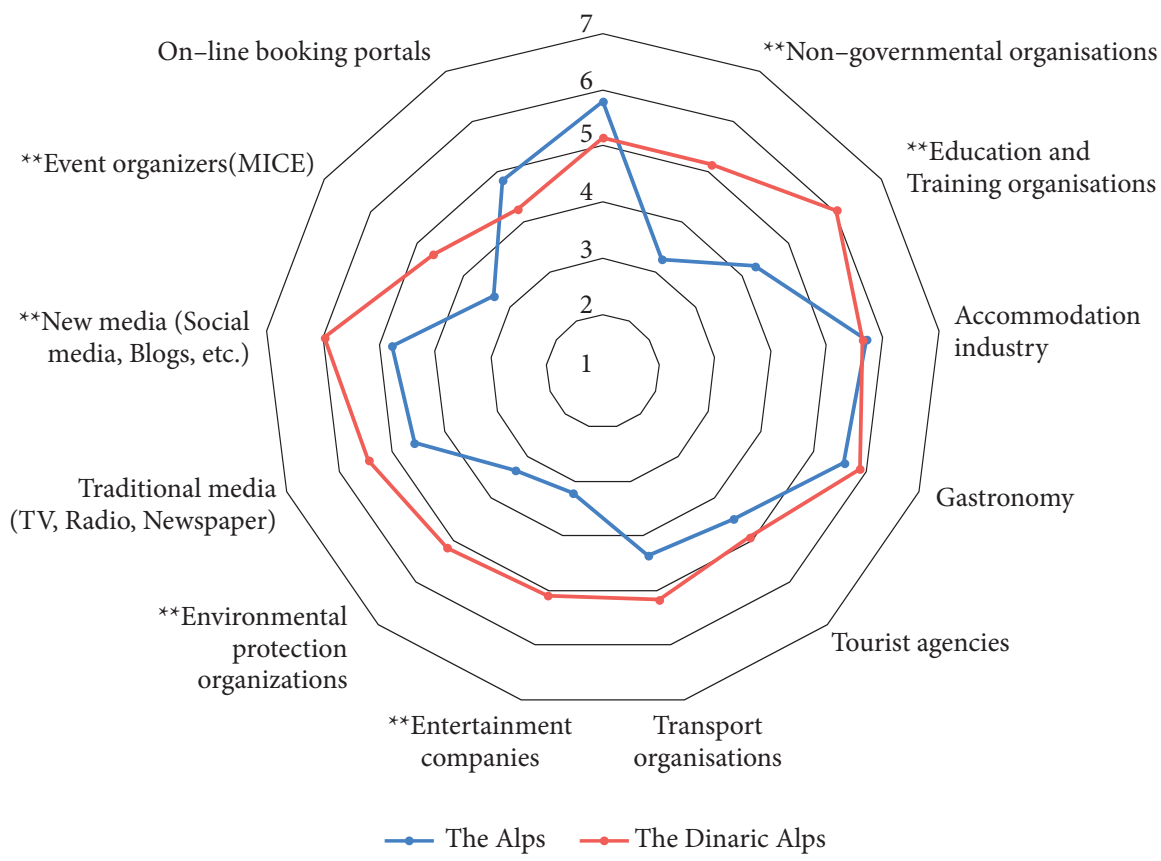

Figure 2: Importance given to different types of stakeholders by the DMO's.

The Dinaric Alps

The Alps
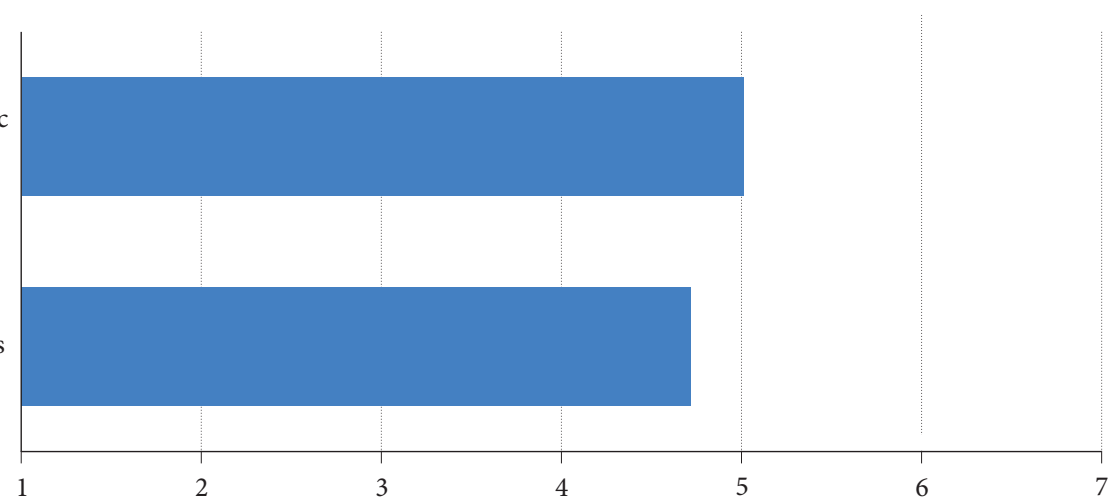

Figure 3: Implementation of sustainability principles in destination planning (self-reported by DMOs). 


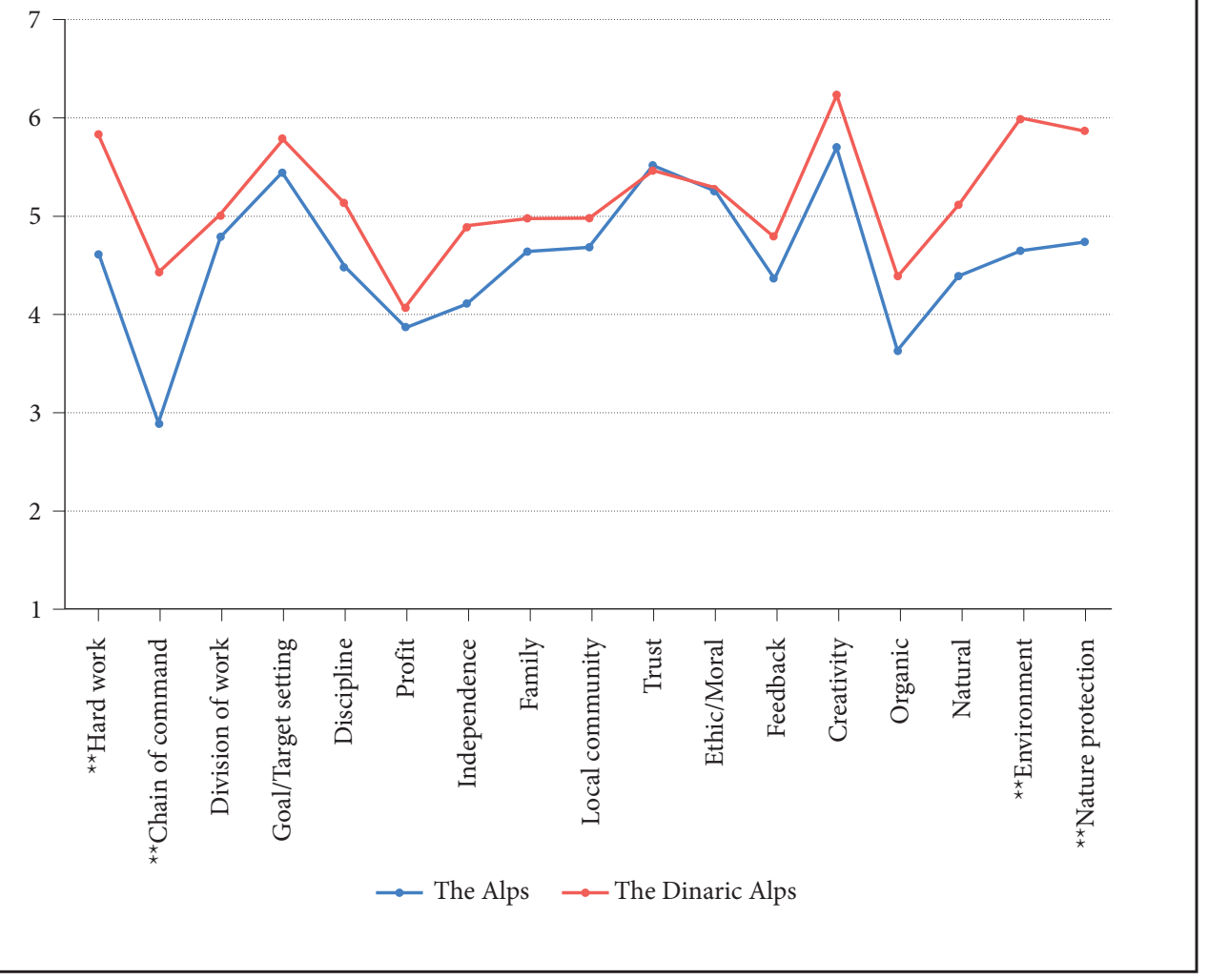

Figure 4: Leadership or management values in the destination.

There is a statistically significant difference between the two mountain regions regarding documents used for planning sustainability regarding environmental protection, as well as laws. In both cases, these were significantly more important in the Dinarides than in the Alps. As shown in Table 1, economic/tourism development documents are the single most important document in the Alps, followed by environmental protection documents and multidisciplinary sustainable development planning documents (ranked first, second and third). In the Dinarides however multidisciplinary sustainable development planning documents are ranked only as a fourth priority. This means that in the Dinarides, environmental protection goals should be put into a broader social context (social and economic). In that sense, there is space for using more multidisciplinary general planning documents of sustainable development in the Dinarides.

Top managers' choices are shown to be affected by their experiences, values and personality (Hambrick 2007; Hambrick and Mason 1984). This applies to DMOs in the same way as it does to other organizations. As shown in Figure 4, leadership or management values such as hard work, chain of command, protection of the environment and protection of nature score more importantly in the Dinarides. In this sense, for DMOs in the Dinarides there is an opportunity to create organizations that are more egalitarian (emphasizing the social equality of all co-workers) and rely less on hierarchy (or the chain of command). Similarly as with documents for planning sustainability, there is a noticeable polarization of answers towards environmental protection in the Dinarides, which also means that there is poorer integration of this aspect with other aspects of sustainability. Conversely, in the Alps, environmental protection of the destination is an aspect of sustainable development that needs additional specialized attention. 
Table 2: Priorities of destination development.

\begin{tabular}{llc}
\hline Feature & \multicolumn{2}{c}{ Likert scores (rank) } \\
\cline { 2 - 3 } & Alps & Dinarides \\
\hline **Tourism research & 4.63 & 5.87 \\
Market research & 4.87 & 5.61 \\
**Use of social media (Linkedln, Facebook, Twitter) & 4.83 & 5.87 \\
**EDI (foreign direct investment) & 2.96 & 5.52 \\
Image and marketing & 5.37 & 5.96 \\
Tourism product development & 6.11 (1st) & 6.17 \\
**Development of infrastructure & $5.72(3 \mathrm{rd})$ & 6.65 (1st) \\
**Destination stakeholder network improvement & 5.09 & 5.91 \\
**Environmental protection & 5.22 & 6.61 (2nd) \\
**Regional or cross-border cooperation & 5.02 & 6 \\
**Human resources development & 4.76 & 6.09 \\
Development of core competencies & 4.98 & 5.48 \\
**SME (small and medium-sized enterprises) support & 4.2 & 5.49 \\
**Service quality & 5.87 (2nd) & 6.57 (3rd) \\
Innovative products & 5.70 & 5.83 \\
Sustainable development & 5.43 & 6.17 \\
Energy efficiency & 4.98 & 5.61 \\
\hline
\end{tabular}

Although there are some differences in terms of leadership or management values, in terms of destination development priorities, there are significant differences (ten out of seventeen are significantly different), as shown in Table 2. This is understandable given the two regions' different levels of economic development. Priorities rated significantly higher in the Dinarides are tourism research, social media use, foreign direct investment, destination stakeholder network improvement, regional and cross-border cooperation and development, human resource development, and SME support. This surely doesn't mean that in the Alps the destination do not have a need for improvements in this areas, but rather that they are already sufficiently developed and are not considered a priority in future development, because these areas are already functional.

When analyzed separately, the priorities of destination development (marked in parentheses) in the Alps are tourism products, service quality, and infrastructure development; in the Dinarides, they are infrastructure development, environmental protection and service quality. Infrastructure development and service quality are priorities for both destinations, but they are rated as significantly more important in the Dinarides. This finding says a great deal about the special importance of these two aspects (improvement of infrastructure and service quality) for the development of mountain destinations in the Dinarides, while at the same time trying to preserve the environment. This is a real challenge of sustainable tourism development in the Dinarides, and also something that should be studied more in future research.

There is a space for investments in accommodation capacities, as well as accompanying IT industry in the Dinarides. An equally important finding concerns DMOs themselves, which should become organizationally less hierarchical (rely less on chain of command-Figure 4), with more employee empowerment in relation to managers or leaders, especially if the same educational structure of employees in both regions is taken into account. Alpine DMOs are significantly less focused on nature protection as a development priority and as a leadership value, and organizations for nature protection have less influence on the DMOs. Bearing in mind the general importance of gastronomy as a stakeholder, and service quality development as a development priority, developing the quality of gastronomic services is recommended in the both mountain regions.

\section{Discussion}

Understanding the relation of the DMO to other destination actors in the mountain destinations is very important because policy changes, related to environmental, social and economic impacts can only be implemented in this DMO-stakeholders nexus. The most important difference in this sense is that in the Alps, 
there is a stronger division between what Franch, Martini and Buffa (2008) identified as primary and secondary stakeholders, as related to power and influence at the destination. The most important stakeholders in the Alps are public institutions, accommodation and gastronomy, whereas the most important stakeholders in the Dinarides are education and training organizations, new media (social media, blogs, etc.), and culinary providers. The relatively low importance of the social dimension in sustainable development in the Dinarides is in line with the findings of Kovačič and Brečko Grubar (2016) regarding knowledge of sustainable development among Slovenian students, who also lack awareness of the social dimension. More importantly, it also confirms the findings of Byrd, Cardenas and Greenwood (2008) in the case of North Carolina, where, the authors emphasize the need to inform destination stakeholders about social issues and how they relate to sustainable development. Consequently, there is still much space in the Dinarides for better stakeholder integration and consultation, and this must be reflected in multidisciplinary general planning documents as evidenced in the literature (Waligo, Clarke and Hawkins 2013; Brida, Osti and Barquet 2010; Shunnaq, Schwab and Reid 2008). The results confirm that in the Alps there is a good transdisciplinary development policy, because of the long tradition in transnational sustainable development, with the challenge of further improving environmental protection. This confirms the findings by Marzelli and Lintzmeyer (2015) that in the macro-region of the Alps, improvements are needed in natural resources management, although significant results have already been achieved so far.

The sustainable tourism literature recognizes that destination planning paradigms are out of date (Waligo, Clarke and Hawkins 2013; Popesku 2011; Goeldner and Ritchie 2009; Krippendorf, Zimmer and Glauber 1985), especially for mountain destinations (Trawoeger 2014; Paunović and Radojević 2014; Blasco, Guia and Prats 2014; Dawson and Scott 2013), because they do not fully take into account broader social and environmental impacts of tourism in order to lessen the impact of the tourism industry on the environment and communities. This is why the results of this study are so important for tourism geography. They demonstrate the lack of interdisciplinarity in planning sustainable tourism in the Dinarides as well as an unused potential of flexible, soft policy instruments (compared to laws) in achieving sustainable tourism.

Leadership is considered an essential part of addressing the "crisis of governance « involving the natural environment (Case et al. 2015; Young et al. 2007), an issue of great importance in mountain destinations, which are ecologically very sensitive (Prideaux 2009). Leadership values constitute an important part of the modern destination management process, in which economic, environmental and social values are all equally important. An important notion is also that not all people that declare themselves in favour of environmental protection really consider this a value because value is something that is a permanent priority and affects actual actions as well as the choice of policy instruments in the broader framework of governance (Smrekar 2011; Hall 2010). Research of declared values in the Dinarides revealed that, regarding DMO organization, hierarchies (i.e., chain of command and hard work) are much more important than in the Alps. This confirms the low priority of the social dimension of sustainability in the Dinarides (such are stakeholder involvement, social inclusion, partner networks, etc.). On the other hand, in the Alps the attitude towards the environment and nature protection at the destination could be improved, as shown in the Figure 4.

The tourism industry has a strong impact on resources at the destination, especially on the local community at the destination, and at the same time the future of the tourist destination also depends on protecting those very same resources (Prideaux 2009; Goeldner and Ritchie 2009). Therefore, research plays an important role in informing those involved in tourism about available development alternatives and priorities while maintaining a holistic and systemic approach in dealing with tourism development (Prideaux 2009; Burns and Novelli 2008). This is particularly true for ecologically sensitive mountain regions such as the Alps and the Dinarides, which is why the results presented results should serve as a basis for further discussion on sustainable tourism development priorities. Why do certain regions have certain priorities, why do these priorities differ, and how do they change over time? Although there are general differences in the social representations of sustainable tourism between the Alps and the Dinarides, individual destinations within both regions can also vary significantly depending on the specific arrangements: the type of organization responsible for coordinating destination development, institutional arrangements and the local resources available (i.e., human, geographic, infrastructure, know-how, tradition, etc.). In this sense, future research on social representations of sustainable tourism should take two directions: 1) research can be conducted on larger samples and in different regions or types of destinations, and 2) a qualitative research approach (i.e., case studies and interviews) should complement the qualitative approach in order to provide greater understanding and interpretation of the results obtained. 


\section{Conclusion}

In order to enhance future sustainable tourism development in the Alps and Dinarides, geography and tourism research should advocate the constant communication of information and upgrading of knowledge of the entire tourism public regarding available development alternatives and priorities, especially taking into account the observed differences. Special emphasis should be put on exchange of best practices and improvement of the quality of all sustainable tourism elements. An important link in this process is understanding the social representations of sustainable mountain tourism. This is because the very same concept, such as sustainable tourism, can have completely different interpretations and social roles in different societies or communities. This study has confirmed that there are differences in this sense, and it has presented a detailed analysis of social representations of sustainable mountain tourism in the Alps and the Dinarides, as a basis for further research on implementing sustainable tourism. There are significant differences in the social representations of sustainable tourism regarding stakeholder prioritization, destination planning, leadership or management values, and destination development priorities.

\section{References}

Bieger, T., Beritelli, P. 2013: Management von Destinationen. München.

Blasco, D., Guia, J., Prats, L. 2014: Emergence of governance in cross-border destinations. Annals of Tourism Research 49. DOI: https://doi.org/10.1016/j.annals.2014.09.002

Borsdorf, A., Bender, O., Braun, F., Haller, A. 2015: Web-based instruments for strengthening sustainable regional development in the Alps. Acta geographica Slovenica 55-1. DOI: https://doi.org/10.3986/AGS.897

Bramwell, B., Lane, B. 2011: Editorial Introduction: Critical research on governance of tourism and sustainability. Journal of Sustainable Tourism 19, 4-5. DOI: https://doi.org/10.1080/09669582.2011.580586

Brida, J. G., Osti, L., Barquet, A. 2010: Segmenting Resident Perceptions towards Tourism-a Cluster Analysis with a Multinomial Logit Model of a Mountain Community. International Journal of Tourism Research 12-5. DOI: https://doi.org/10.1002/jtr.778

Burns, P., Novelli, M. 2008: Introduction: The Majority World Development and Tourism. Tourism Development-Growth, Myths and Inequalities. Oxfordshire. DOI: https://doi.org/10.1079/ 9781845934255.0000

Byrd, E. T., Cardenas, D. A., Greenwood, J. B. 2008: Factors of Stakeholder Understanding of Tourism: The Case of Eastern North Carolina. Tourism and Hospitality Research 8-3. DOI: https://doi.org/ 10.1057/thr.2008.21

Case, P., Evans, L. S., Fabinyi, M., Cohen, P. J., Hicks, C. C., Prideaux, M., Mills, D. J. 2015: Rethinking environmental leadership: The social construction of leaders and leadership in discourses of ecological crisis, development, and conservation. Leadership 11-4. DOI: https://doi.org/10.1177/1742715015577887

Dawson, J., Scott, D. 2013: Managing for climate change in the alpine ski sector. Tourism Management 35. DOI: httpss:/doi.org/10.1016/j.tourman.2012.07.009

Dunphy, D., Benveniste, J. 2000: An introduction to the sustainable incorporation. Poslovna etika i komuniciranje. Beograd.

Finkelstein, S., Hambrick, D., Cannella, A. J. 2009: Strategic leadership: Theory and research on executives, top management teams and boards. New York.

Franch, M., Martini, U., Buffa, F. 2008: Strategie di brand management nelle destinazioni alpine community. Mercati e competitivita 4.

Goeldner, C. R., Ritchie, J. R. 2009: Tourism Principles, Practices, Philosophies. Hoboken.

Gössling, S., Scott, D. 2012: Scenario planning for sustainable tourism: an introduction. Journal of sustainable tourism 20-6. DOI: https://doi.org/10.1080/09669582.2012.699064

Hall, M. C. 2010: Policy Learning and policy failure in sustainable tourism governance: from first and second order to third order change? Journal of Sustainable Tourism 19, 4-5. DOI: https://doi.org/10.1080/ 09669582.2011.555555

Hambrick, D. 2007: Upper Echelons Theory: An Update. Academy of Management Review 32-2. DOI: https://doi.org/10.5465/AMR.2007.24345254 
Hambrick, D., Mason, P. 1984: Upper Echelons: The Organization as a Reflection of Its Top Managers. Academy of Management Review 9-2. DOI: https://doi.org/10.5465/AMR.1984.4277628

Kovačič, G., Brečko Grubar, V. 2016: Knowledge of sustainable development among geography students in Slovenia. Acta geographica Slovenica 56-1. DOI: https://doi.org/10.3986/AGS.1633

Krippendorf, J., Zimmer, P., Glauber, H. 1985: Für einen anderen Tourismus. Frankfurt am Main.

Marzelli, S., Lintzmeyer, F. 2015: Transnational needs of sustainable spatial development in the Alps: results from an analysis of policy documents. Acta geographica Slovenica 55-2. DOI: https://doi.org/10.3986/ AGS.1585

Moscardo, G. 2005: Peripheral tourism development: Challenges, Issues and Success Factors. Tourism Recreation Research 30-1. DOI: https://doi.org/10.1080/02508281.2005.11081231

Moscardo, G. 2011: Exploring social representations of tourism planning: issues for governance. Journal of Sustainable Tourism 19, 4-5. DOI: https://doi.org/10.1080/09669582.2011.558625

Moscovici, S., Duveen, G. 2000: Social Representations: Explorations in Social Psychology. Cambridge.

Paunović, I., Radojević, M. 2014: Towards green economy: balancing market and seasonality of demand indicators in Serbian mountain tourism product development. Trends in Tourism and Hospitality Industry. Opatija.

Pechlaner, H., Kozak, M., Volgger, M. 2014: Destination leadership: a new paradigm for tourist destinations? Tourism Review 69-1. DOI: https://doi.org/10.1108/TR-09-2013-0053

Popesku, J. 2011: Menadžment turističke destinacije. Belgrade.

Prideaux, B. 2009: Resort Destinations-Evolution, Management and Development. Oxford.

Shunnaq, M., Schwab, W. A., Reid, M. F. 2008: Community development using a sustainable tourism strategy: a case study of the Jordan River Valley touristway. International Journal of Tourism Research 1-14. DOI: https://doi.org/10.1002/jtr.620

Smrekar, A. 2011: From environmental awareness in word to environmental awareness in deed: The case of Ljubljana. Acta geographica Slovenica 51-2. DOI: https:/doi.org/10.3986/AGS51203

Trawoeger, L. 2014: Convinced, ambivalent or annoyed: Tyrolean ski tourism stakeholders and their perceptions of climate change. Tourism Management 40. DOI: https://doi.org/10.1016/j.tourman.2013.07.010

Volgger, M., Pechlaner, H. 2015: Governing networks in tourism: what have we achieved, what is still to be done and learned? Tourism Review 70-4. DOI: https://doi.org/10.1108/TR-04-2015-0013

Waligo, V. M., Clarke, J., Hawkins, R. 2013: Implementing sustainable tourism: A multi-stakeholder involvement management framework. Tourism Management 36. DOI: https://doi.org/10.1016/ j.tourman.2012.10.008

WCED - World commision on environment and development: Our common future - Brutland report. Oxford, 1987.

Yasarata, M., Altinay, L., Burns, P., Okumus, F. 2010: Politics and sustainable tourism development - Can they co-exist? Voices from North Cyprus. Tourism Management 31-3. https://doi.org/10.1016/ j.tourman.2009.03.016

Young, O. R., Osherenko, G., Ekstrom, J., Crowder, L. B., Ogden, J., Wilson, J. A., Peach, R. 2007: Solving the Crisis in Ocean Governance: Place-Based Management of Marine Ecosystems. Environment 49-4. DOI: https://doi.org/10.3200/ENVT.49.4.20-33 